\title{
Impact of Front Line Demonstration on Yield and Economics of Pigeon Pea, Cajanus cajan in the District of Ramanagara, Karnataka, India
}

\author{
G. Keshavareddy, S. Kamala Bai*, K.H. Nagaraj and S.C. Ranganath \\ Krishi Vigyan Kendra, Chandurayanahalli, Kalya Post, Magadi Taluk, \\ Ramanagara District, Karnataka State, India \\ *Corresponding author
}

\begin{abstract}
A B S T R A C T
The frontline demonstrations (FLD's) on BRG-5 variety of pigeon pea were conducted by Krishi Vigyan Kendra of Ramanagara District, Karnataka State. Initially farm trials of BRG-5 variety were conducted during 2012-13 and was released by University of

Keywords

Pigeon pea, BRG-5,

Front line

demonstration,

Farmers practice

Article Info

Accepted:

04 December 2017

Available Online:

10 January 2018

Agricultural Sciences, Bengaluru during 2014-15, which is resistant to wilt. Improved cultivation practices were demonstrated in farmer's fields for three consecutive years. The results of the demonstrations showed higher yields compared to traditional farmer's practices followed for pigeon pea cultivation. The average increased per cent seed yield is 38.47 over the years from front line demonstrations compared to check plots. However, during the year 2015-16, the per cent increase in seed yield was 65.42. The huge variation in the per cent increase in the yield was due to scanty rainfall and major variations in farmer's practices adopted in the cluster villages. The other parameters like extension gap, technological gap and technology index were derived for assessment of technology adoption rate. The average technology gap and technological index were 6.08 and 33.72 per cent, respectively. The results clearly indicated the positive impact of front line demonstrations over the farmers' practices towards enhancing the productivity of pigeon pea cultivation under rainfed conditions in Ramanagara district of Karnataka state, India. Demonstrated technologies proved more remunerative and economically feasible compared to farmers traditional practices in pigeon pea cultivation.
\end{abstract}

\section{Introduction}

Pigeon pea, Cajanus cajan (L) Millsp is the second most important pulse crop in India after Chickpea. It has multiple uses and occupies an important place in the prevailing farming systems in the country. It plays an important role in sustainable agriculture by enriching the soil nutrients through biological nitrogen fixation. In addition, because of its deep root system it is a boon for the farmers to grow under rainfed condition. Karnataka is one of the major pigeon pea growing state in the country ranking second in area (8.9 lakh hectares) with 5.3 lakh tones of production (2010-11) with an average productivity of 625 $\mathrm{kg}$ per hectare. In Southern Karnataka, Ramanagara district is famous for red gram cultivation occupying an area of 5030 hectare with an average productivity of $452 \mathrm{~kg} / \mathrm{ha}$, which is much lower than the state and national average of productivity. 
Though pigeon pea is widely grown in Ramangara district, various factors influences potential yield of the crop such as, faulty sowing practices, lack of knowledge about high yielding and diseases resistant varieties, (Fusarium wilt and sterility mosaic diseases are severe in the district) lack of awareness about seed treatment (with biofertilizers viz., Rhizobium and Phosphorous Solubilizing Bacteria and bio-agent Trichoderma viridae), improper management of pod borer, (Helicoverpa) and lack of knowledge about timely intercultural operations. Above all these, in the district, predominantly noticed problems for pigeon pea cultivation are high incidence of wilt and uneven distribution of rainfall. With this background, initially farm trials of BRG-5 pigeon pea and later Front Line Demonstrations (FLD's) were conducted to show the worth of high yielding and wilt resistant BRG-5 variety of pigeon pea.

\section{Materials and Methods}

Initially farm trials were conducted during the year 2012-13 with an objective to assess the performance of new variety BRG-5 at different locations with locally widely grown pigeon pea variety BRG-2 (as check) at field situations of Ramangara district.

The trails were undertaken in ten farmer's plot in an area of 10 guntas each. Observations on wilt incidence were taken after $50 \%$ of flowering of the crop. In each farmer's trial plot, 100 plants were observed for wilt incidence of both BRG-5 and BRG-2 varieties. Later the per cent wilt incidence was calculated by total number of plants observed and number of plants infected as follows.

Numbers of plants showing wilt symptoms

Percent wilt incidence $=$----------------- X 100

Total number of plants observed
The data on pod borer, Helicoverpa armigera, damage caused to pods, growth and yield parameters observations were taken at the time of harvest from randomly selected ten plants in each farmers plot and average was worked out.

Based on the outcome of the farm trials result, front line demonstrations (FLD's) were organized consecutively for three years from 2013 to 2016 in farmer's fields. The front line demonstrations were conducted with the objective of demonstrating and creating awareness about newly released wilt resistant pigeon pea variety BRG-5.

Improved agronomic practices viz., recommended dosage of fertilizers application (10:20:10 kg NPK/acre), seed treatment with rhizobium and phosphate solubilizing bacteria ( $40 \mathrm{~g} / \mathrm{kg}$ of seeds), Trichoderma viridae (10g $/ \mathrm{kg}$ of seeds) were demonstrated.

At flowering stage spraying of pulse magic $(10 \mathrm{~g}$ per $\mathrm{lt}$ of water) and erection of Helicoverpa pheromone traps ( 5 to 6 per acre) were also demonstrated. Based on pheromone trap catches, farmers were advised to take up management practices against Helicoverpa, which is a major pest on pigeon pea. The growth and yield parameters were recorded in farm trails plots but only yield data was collected from the demonstrations by random crop cutting method. Qualitative data was converted into quantitative form by using following formulae and expressed in terms of per cent increase in yield.

Plot per cent increase in yield $=$

$$
\begin{gathered}
\begin{array}{c}
\text { Seed yield under } \\
\text { Demo plot }
\end{array} \\
\begin{array}{c}
\text { Seed yield under } \\
\text { farmers Practice }
\end{array} \\
\begin{array}{c}
\text { Seed yield under } \\
\text { farmers practice plot }
\end{array}
\end{gathered}
$$


The extension gap, technology gap and technology Index, Benefit cost ratio (BCR) were worked out as per Samui et al., (2000), as given below.

Extension gap $=$ Demonstration plot yield farmers practice plot yield

Technology Gap = Potential yieldDemonstrated yield

Technology Index $(\%)=\frac{\text { Technology gap }}{\text { Potential yield }}$

\section{Results and Discussion}

The Farm trials and front line demonstrations studies were carried out at various locations of Ramanagara district of Karnataka state in Kharif season from 2012 to 2016. Results of the farm trials conducted during 2012-13 are presented in Table 1. It was observed that there was no wilt incidence in BRG-5 plots, as it proved resistant to Fusarium wilt while, BRG-2 was found susceptible to wilt. The average per cent wilt observed was 22.8 during 2012-13.The improved technologies imparted to farmers in comparison to farmers practice and the gap in the technology adoption observed under farmer's practices over improved and demonstrated technology practices in cultivation of pigeon pea is presented in Table 2. It was observed that 100 per cent gap was found in adoption of new variety, seed treatment, gypsum application, and proper use of plant protection measures where as $57 \%$ technology gap was found in adopting fertilizer application.

From the study it was noticed that farmers were not aware of seed treatment with rhizobium and Phosphate Solubilizing Bacteria, followed thick sowing, applied indiscriminate amount fertilizers and inappropriate use of chemicals to control pests and diseases. Added to this, farmers were ignorant about the new variety BRG-5 which is resistant to wilt disease and were growing BRG-2 in the district, which is highly susceptible for wilt disease in wilt prone areas resulting in $60-70 \%$ crop losses. Wilt in pigeon pea is caused by Fusarium udum and the fungus is both seed and soil borne and survives without main host for many years in the soil. In BRG-2 pigeon pea, initially wilt symptoms are observed after 30-45 days of sowing. The disease severity was high during flowering period, where yellowing of the leaves followed by partial or complete pre mature death of plants occurs in clusters. In BRG-5 plots, the average per cent pod damage by Helicoverpa armigera was 2.22, where integrated pest management practices were followed but the average per cent pod damage was very high $(17.28 \%)$ in check plot (BRG2 ), where farmers practices were followed. Disease and pest incidence combined effect results in huge crop loss and reduction in yield.

The three year front line demonstration results are presented in Table 3. The average seed yield recorded in demonstration (BRG-5) plot was $11.89 \mathrm{q} / \mathrm{ha}$ compared to farmers practice plots $(9.03 \mathrm{q} / \mathrm{ha})$. The highest average yield in FLD plots recorded was $15.12 \mathrm{q} / \mathrm{ha}$ during the year 2014-15, where as in farmers plots, it was $12.4 \mathrm{q} / \mathrm{ha}$ during the same year. The lowest average yields recorded both in demonstrated plots $(8.85 \mathrm{q} / \mathrm{ha})$ and farmers practice plots (5.35 q/ha) during the year 2015-16 was mainly due to prolonged drought like situation during flowering and pod maturation stage.

The results clearly indicated that highest average seed yield $(11.93 \mathrm{q} / \mathrm{ha})$ in demonstration plots over the years compared to farmers practice $(8.99 \mathrm{q} / \mathrm{ha})$ is due to integrated crop management practices and awareness of new variety BRG-5 which is a wilt resistant variety. Adoption of scientific package of practices like seed treatment with bio-fertilizers and need based right plant protection practices resulted in higher yields. 
The above findings are similar in lines with Singh, 2002 and Raju et al., 2015.

Based on the observations made, Extension gap, Technology gap and Technology index were worked out. Extension gap is the difference between demonstrated plot yield and farmers practice plot yield (check). The extension gap observed during different years was $2.59,2.72$ and $3.50 \mathrm{q} /$ ha during 2013-14, 2014-15 and 2015-16, respectively. On an average, extension gap observed in three years under FLD implemented villages was 3.04 $\mathrm{q} /$ ha. The highest extension gap $3.50 \mathrm{q} / \mathrm{ha}$ was recorded in 2015-16 followed by $2.72 \mathrm{q} / \mathrm{ha}$ (2014-15) and 2.50 q/ha (2013-14).

Higher extension gap emphasizes that there is a need to educate farmers for adoption of improved production technologies through various extension methods such as method demonstrations of seed treatment with biofertilizers \& Trichoderma, line sowing with proper seed rate, application of fertilizers based on soil test results and spraying of proper plant protection chemicals at right dose $\&$ right time.

Subsequently these technologies may replace the conventional practices, thus reversing the trend of wide extension gap. Further, the higher extension gap observed during 2015-16 even after three years of introduction of new variety BRG-5 might be because of the fact that FLD was taken in new cluster villages where wilt severity was more on BRG-2 and also scanty rainfall in the area during the cropping period.

Technology gap is the difference between potential yield and demonstrated plot yield. The results indicated a gap of $6.18,2.88$ and 9.15 q/ha during 2013-14, 2014-15 and 201516 respectively. The average technology gap for three years where FLD was implemented is $6.09 \mathrm{q} / \mathrm{ha}$. The technology gap observed may be attributed to dissimilarities in the physical, chemical and biological soil status, agronomic practices adopted by farmers and local climatic conditions prevailed in the respective locations where FLD's were taken. Lower the value of the technology gap, more is the feasibility of the technologies which could be easily adopted by the farmers as they are user friendly.

Technology Index was calculated as per the formula mentioned in materials and methods. The technology index shows the feasibility of evolved technology at the farmer's fields. Lower the value of technology Index more is the practicability of the technology, where farmers could easily adopt at field level. The technology Index varied from 16.67 to 50.83 $\%$ (Table 3). As such fluctuation in technology index (ranging from 16.67 to 50.83) during the study period in certain locations may be attributed to the dissimilarities in soil fertility status, weather conditions, improper intercultural operations, pest and diseases management practices etc.

On an average the technology index observed was $33.94 \%$ for three years where front line demonstrations were conducted. This shows the efficiency and effectiveness of the improved technologies as a result of successful technical interventions. Thus achieving higher yields nearest to potential yields will accelerate the adoption of demonstrated technical interventions to increase the yield performance of pigeon pea.

Economic returns related to input and output prices of commodities prevailed during the study period, were recorded. The cultivation of pigeon pea under improved technologies (FLD's) gave higher net returns of Rs. 23122, Rs. 43184 and Rs.39800 as against to farmers practices i.e., Rs.16261, 18558 and 18373 per hectare during the years 2013-14,2014-15 and 2015-16, respectively (Table 3). Similar results were corroborated with Singh et al., 2014 and Raj et al., 2013 findings. 
Table.1 Assessment of Pigeon Pea Variety BRG-5 and BRG-2 for wilt and pod borer damage

\begin{tabular}{|c|c|c|c|c|c|c|c|c|c|c|c|c|c|c|c|c|}
\hline \multirow[t]{2}{*}{$\begin{array}{l}\text { Trial } \\
\text { No. }\end{array}$} & \multicolumn{2}{|c|}{$\begin{array}{l}\text { Plant height } \\
\text { (cm) }\end{array}$} & \multicolumn{2}{|c|}{$\begin{array}{c}\text { Days to } 50 \% \\
\text { flowering }\end{array}$} & \multicolumn{2}{|c|}{$\begin{array}{l}\text { Days to } \\
\text { maturity }\end{array}$} & \multicolumn{2}{|c|}{$\begin{array}{c}\text { Branches } \\
\text { /plant }\end{array}$} & \multicolumn{2}{|c|}{$\%$ wilt } & \multicolumn{2}{|c|}{$\begin{array}{c}\text { Pod bored } \\
\text { damage }(\%)\end{array}$} & \multicolumn{2}{|c|}{ Pods/plant } & \multicolumn{2}{|c|}{ Seed yield (kg/ha). } \\
\hline & BRG-5 & BRG-2 & BRG-5 & BRG-2 & BRG-5 & BRG-2 & BRG-5 & BRG-2 & BRG-5 & BRG-2 & BRG-5 & BRG-2 & BRG-5 & BRG-2 & BRG-5 & BRG-2 \\
\hline 1 & 241 & 213 & 147 & 136 & 180 & 170 & 14 & 12 & 0 & 19 & 3.8 & 13.4 & 328 & 138 & 1703 & 982 \\
\hline 2 & 225 & 202 & 145 & 132 & 185 & 172 & 13 & 12 & 0 & 21 & 1.3 & 16.2 & 254 & 143 & 1805 & 1055 \\
\hline 3 & 210 & 193 & 149 & 135 & 183 & 174 & 15 & 11 & 0 & 13 & 1.8 & 17.6 & 197 & 152 & 1910 & 1386 \\
\hline 4 & 223 & 207 & 144 & 133 & 179 & 168 & 14 & 10 & 0 & 28 & 1.4 & 18.5 & 193 & 159 & 1987 & 1224 \\
\hline 5 & 215 & 196 & 143 & 131 & 186 & 171 & 14 & 11 & 0 & 31 & 2.5 & 19.0 & 209 & 163 & 2087 & 1415 \\
\hline 6 & 210 & 189 & 146 & 134 & 185 & 173 & 14 & 11 & 0 & 24 & 2.8 & 22.2 & 256 & 178 & 2012 & 1325 \\
\hline 7 & 220 & 197 & 124 & 115 & 190 & 176 & 13 & 10 & 0 & 32 & 1.9 & 18.4 & 264 & 171 & 1987 & 1185 \\
\hline 8 & 118 & 196 & 127 & 119 & 186 & 175 & 15 & 13 & 0 & 23 & 2.1 & 15.2 & 215 & 158 & 1853 & 1328 \\
\hline 9 & 221 & 192 & 148 & 135 & 187 & 179 & 15 & 11 & 0 & 37 & 1.4 & 13.1 & 204 & 178 & 1824 & 1045 \\
\hline 10 & 225 & 204 & 145 & 134 & 184 & 169 & 16 & 12 & 0 & 25 & 3.2 & 19.2 & 389 & 183 & 1897 & 1238 \\
\hline Mean & 210.7 & 198.9 & 141.8 & 130.4 & 184.5 & 172.7 & 14.3 & 11.3 & 0 & 22.8 & 2.22 & 17.28 & 250.9 & 162.3 & 1906.5 & 1218.3 \\
\hline
\end{tabular}


Table.2 Gap in adoption of improved pigeon pea cultivation practices among farmers

\begin{tabular}{|c|c|c|c|c|}
\hline No. & Technology & Improved practices & Farmers practices & Technology Gap (\%) \\
\hline 1 & Variety & $\begin{array}{l}\text { BRG-5- ( wilt Resistant } \\
\text { variety ) }\end{array}$ & $\begin{array}{l}\text { BRG }-\underset{1}{2} \text { (wilt } \\
\text { susceptible variety) }\end{array}$ & 100 \\
\hline 2 & Seed rate & $6 \mathrm{~kg} / \mathrm{ha}$ & $8 \mathrm{~kg} / \mathrm{ha}$ & High Seed rate \\
\hline 3 & Seed Treatment & $\begin{array}{l}\text { With Nitrogen fixing, } \\
\text { PSB and Trichoderma }\end{array}$ & Not Followed & $100 \%$ \\
\hline 4 & $\begin{array}{lll}\text { Fertilizer dose } & \text { (Major } \\
\text { Nutrients) } & & \end{array}$ & $\begin{array}{l}\text { As per POP based on } \\
\text { soil test results. }\end{array}$ & $\begin{array}{l}\text { Non judicious } \\
\text { application of fertilizers }\end{array}$ & $57 \%$ \\
\hline 5 & Gypsum & $160 \mathrm{~kg} / \mathrm{acre}$ & Not followed & $100 \%$ \\
\hline 6 & Plant Protection Measures & $\begin{array}{l}\text { Integrated } \\
\text { Management }\end{array}$ & $\begin{array}{l}\text { Indiscriminate use of } \\
\text { pesticides }\end{array}$ & $100 \%$ \\
\hline
\end{tabular}

*POP- Package of practices

Table.3 Technology gap, Extension gap and Technology Index in Pigeon Pea cultivation

\begin{tabular}{|c|c|c|c|c|c|c|c|}
\hline \multirow[t]{2}{*}{ Year } & \multirow{2}{*}{$\begin{array}{l}\text { Potenti } \\
\text { al yield } \\
\text { (q/ha) }\end{array}$} & \multicolumn{2}{|c|}{ Average seed yield (q/ha) } & \multirow{2}{*}{$\begin{array}{l}\text { Increase in } \\
\text { yield over } \\
\text { farmers } \\
\text { practice }\end{array}$} & \multirow{2}{*}{$\begin{array}{l}\text { Extension } \\
\operatorname{Gap}(\mathbf{q} / \mathbf{h a})\end{array}$} & \multirow{2}{*}{$\begin{array}{l}\text { Technology } \\
\text { Gap (q/ha) }\end{array}$} & \multirow{2}{*}{$\begin{array}{l}\text { Technology } \\
\text { Index }(\%)\end{array}$} \\
\hline & & $\begin{array}{l}\text { Demonstrated } \\
\text { plot (FLD) }\end{array}$ & $\begin{array}{l}\text { Farmers } \\
\text { practice } \\
\text { (check) }\end{array}$ & & & & \\
\hline 2013-14 & 18 & 11.82 & 9.23 & 28.06 & 2.59 & 6.18 & 34.33 \\
\hline 2014-15 & 18 & 15.12 & 12.4 & 21.93 & 2.72 & 2.88 & 16.00 \\
\hline 2015-16 & 18 & 8.85 & 5.35 & 65.42 & 3.50 & 9.15 & 50.83 \\
\hline Mean & 18 & 11.93 & 8.99 & 38.47 & 3.04 & 6.07 & 33.72 \\
\hline
\end{tabular}

Table.4 Comparison of economics of pigeon pea cultivated under FLD and farmers field (check)

\begin{tabular}{|l|l|l|l|l|l|l|l|l|}
\hline \multicolumn{1}{|c|}{ Year } & \multicolumn{2}{|c|}{ Cost of Cultivation } & \multicolumn{2}{c|}{ Gross return } & \multicolumn{2}{c|}{ Net Return } & \multicolumn{2}{c|}{ B:C ratio } \\
\hline & Demo & Check & Demo & Check & Demo & Check & Demo & Check \\
\hline $\mathbf{2 0 1 3 - 1 4}$ & 22560 & 32689 & 45682 & 48950 & 23122 & 16261 & 2.02 & 1.49 \\
\hline $\mathbf{2 0 1 4 - 1 5}$ & 33191 & 44084 & 76375 & 62642 & 43184 & 18558 & 2.30 & 1.42 \\
\hline $\mathbf{2 0 1 5 - 1 6}$ & 26500 & 19800 & 66400 & 40100 & 39800 & 20300 & 2.51 & 2.03 \\
\hline Mean & 27417 & 31391 & 62819 & 50564 & 35368 & 18373 & 2.28 & 1.64 \\
\hline
\end{tabular}

The Benefit: Cost ratio of pigeon pea during 2013-14, 2014-15 and 2015-16 under improved cultivation practices were 2.02, 2.30 and 2.51 , respectively while it was 1.49 , 1.42 and 2.03 under farmers practice for the respective years. The higher net return in demo plots is attributed to higher yields due to proper seed rate and also reduction in cost of cultivation. Adoption of correct dosage and timely application of specific chemicals reduced the plant protection cost (Table 4). The higher cost benefit ratio in demo plots is because of higher yields obtained under improved technologies compared to farmer's practices during all the three years. These results are in corroboration with the findings of Mokidue et al., (2011).

This study shows how the non-availability of the quality and suitable seed material 
maintaining the optimum plant population, inadequate and imbalance dose of fertilizers application especially nitrogen and phosphorous fertilizers (without potassium), untimely inter cultivation operations and plant protection measures affect the potential yield in pigeon pea. Further timely sowing and by adopting good agronomic practices along with integrated pest and diseases management practices, farmers can get higher yields in pigeon pea by minimizing the cost of cultivation and maximizing the total returns. The productivity gained by demonstrations over conventional practices created awareness among the famers and motivated the other farmers to adopt appropriate improved production and protection technologies in pigeon pea cultivation.

\section{References}

Mokidue, I., A.K. Mohanty, and Sanjay K., 2011. Correlating growth yield and adoption of Urdbean technology. Indian J. Extn.Edu. 11 (2): 20-24.

Raj, A.D., V. Yadav and Rathod, J.H. 2013.
Impact of front line Demonstration on the yield of pulses. Int. J. Sci. Res. Public. 3(9), 2250-2254

Raju. G.T., D.H Patil, A. Naik, B. Zaheer Ahmed and Patil M.C., 2015. Impact of frontline demonstration on the yield and economics of Pigeon pea in Kalburghi district of Karnataka State, Int. J. Sci. Nature, 6: 224-227,

Samui, S.K., S. Maitra, D.K. Roy, A.K. Mandal and Saha D. Roy, D.K., Mandal. A.K. and Saha D, 2000. Evaluation of front line demonstration on groundnut. J. Indian Soc. Coastal Agril. Res. 18(2): 180-183

Singh,.D., A.K. Patel., S.K. Baghel, M.S. Singh, A. Singh and Singh, A.K. 2014. Impact of front line demonstration on the yield and economics of Chickpea in Sindhi district of Madhya Pradesh. J. Agril. Res. 1 (1) 22-25.

Singh, P.K., 2002. Impact of participation in planning on adoption of new technology through front Line demonstration, MANAGE. Extn. Res. Rev., 45-48.

\section{How to cite this article:}

Keshavareddy, G., S. Kamala Bai, K.H. Nagaraj and Ranganath, S.C. 2018. Impact of Front Line Demonstration on Yield and Economics of Pigeon Pea, Cajanus cajan in the District of Ramanagara, Karnataka, India. Int.J.Curr.Microbiol.App.Sci. 7(01): 472-478.

doi: https://doi.org/10.20546/ijcmas.2018.701.056 